\title{
ACCOUNTING FOR RISKS OF USING SHALLOW GROUND WATER FOR SECONDARY CROPS ON LOWLAND PADDY FIELDS IN INDONESIA
}

\author{
D. Useng ${ }^{1,2}$
}

\begin{abstract}
Most paddy fields in Indonesia laid on the lowland area and many of them have not sufficient water supply during the dry period. To maximize the use of land, some farmers planted secondary crops using the available shallow water table along the coastal areas. Some common plants planted during dry period on the lowland paddy fields are corn (Zea mais), soybean (Glycine max), groundnut (Arachis hypogaea), chili pepper (Capsicum annum), tomato (Lycopersicum esculentum) and mungbean (Phaseolus radiatus). The use of secondary crops on paddy fields using shallow ground water embedded some potential risks that need to be counted. The study conducted to model the risks (production and market risks) associated with the ground water quality and irrigation application methods on the net returns on several crops under different irrigation treatments and application uniformities. Six crops were analyzed to show the potential return under furrow and border irrigation scenarios. Economic reliability measured in terms of Discounted Cash Flow performance of each type of crop. The risk analysis reveals that the three type of crops i.e. tomato, chili pepper and groundnut shows stochastic dominances over the other three crops means that the crops are less risky than to the other three. The model sensitivity analysis performed to show the influence of input variables to the model outputs and the result shows the commodity prices, inflation and ground water salinity are most sensitive to influence the model output.
\end{abstract}

Keywords: Lowland Paddy fields, irrigation, water quality, risk analysis.

\section{INTRODUCTION}

Paddy fields in South Sulawesi province of Indonesia is about 582,000 ha consisted of 156,081 ha of technical irrigated, and the rest consisted of semi-technically irrigated, simple irrigated and rainfed (CBS 2010). The paddy fields are mostly located in the lowland plains along the coast line of the province. Crops (mostly rice) are planted twice on average a year mostly from October to January, and March to May with a fallow period from June to October. The low land paddy fields laid on the shallow ground water table that required only simple mechanism to bring it to the surface for irrigation purposes.

The South Sulawesi government intended to enhance food crop production in this region to support the national food policy to be self-sufficient in food production in coming years. To implement the program, some attempts have been made to utilize available paddy fields for secondary crop production during the dry seasons. Secondary crop planting starts at the beginning of the dry season when soil water still available on the upper layer of the soil profile after the rice plant has been harvested. The main secondary crops planted during this season are Corn (Zea mais), Soybean (Glycine max), Groundnut (Arachis hypogaea), Chili Pepper (Capsicum annum), Tomato (Lycopersicum esculentum) and Mungbean (Phaseolus radiatus).

To utilize the available shallow water table to irrigate the crops, farmers usually dig some shallow wells at several locations in the field and manually tap water from the wells. These practices sometimes lead to the massive crop failures due to the lack of labor for irrigation activities. Data from Agricultural statistics (1994) recorded that the total failure of the Mungbean crop in South Sulawesi due to drought was 2,711 Ha, which comprises $99 \%$ of the total crop failure of the country $(2,712 \mathrm{Ha})$. In 2010 the corn production of the province was 1.3 million tons with productivity of 4.4 t/ha (CBS 2011).

The objective of this study are: 1) to evaluate the appropriate irrigation technology to utilize the shallow ground water on the paddy field; 2) to calculate the potential crops that most efficient in terms of economic values and 3) to analyze the potential risks embedded in the development of secondary crops.

\footnotetext{
${ }^{1}$ Dept. of Agricultural Engineering, Hasanuddin University, Makassar 90245, INDONESIA

${ }^{2}$ Center for Nat. Resources R\&D Hasanuddin University, Makassar 90245, INDONESIA

Note: Discussion on this paper is open until December 2013
} 
The nature of the low land paddy fields along the coastal region have high prospective to be utilized in order to enhance the small holder farmer's income by utilizing the available shallow water table. The lowland fields are mostly consisting of sandy soils with water table deep at 2 to $5 \mathrm{~m}$ below the ground surface. This available shallow water table in lowland areas has potential to increase land productivity by applying low cost irrigation technology to lift and distribute the water to the crops planted on the paddy fields. The existences of shallow groundwater along the coastal regions are different both in quantity and quality. The range of salinity level depends on location especially the land along the coastal lines are prone to the salt water intrusion. The saline water intrusion was reported been occurs around the Ujung Pandang (Makassar) region, with chlorine $(\mathrm{Cl})$ level between $400-600 \mathrm{mg} / \mathrm{l}$. (Ind. Directorate of Environmental Geology 1998). Further major problem associated with paddy fields on the lowland region are the sandy textured soil that has a high infiltration rate especially when the hardpan below the surface is disturbed.

In most of the time, labors are available during the dry seasons partly because there are not many alternative jobs available for the farmers and many of farm machineries and draught animals are available to be utilized. In order to evaluate the appropriate irrigation technology, and to identify the most promising crops suitable to be grown on the paddy fields during the dry season, this research is conducted using the risk analysis to show the stochastic dominance of crops under study.

\section{METHOD}

The research simulates two different irrigation technologies applied on the system, i.e., furrow irrigation and border irrigation. The performance of each system simulated using the SRFR (USDA) model to determine the optimum design of the system, i.e., required discharge, furrow or border length, operation time and pump capacity, and the model results are used to determine the economic (investment) values of the system in the farm budget.

The crops economic performances under certain irrigation application (either furrow or border system) evaluated in terms of discounted cash flow (DCF) method with measures such as net cash flow of net present value (NPV) and benefit cost ratio (BCR). The uncertainties in the development of each crop type introduced in the risk analysis. Three risk analyses are assessed i.e., production risk, financial risk and market risk. The production risks introduce the uncertainty associated with water quality, financial risk considering uncertainty in depreciation, tax and inflation, and the uncertainty related to market risks covers commodity prices (Anderson and Dillon, 1992). The uncertainty of variables is introduced in to the formulas as distribution functions and Montecarlo sampling (Hardaker et al. 1997 ) is applied to reconstruct the probability distribution function of the system under study.

The risk program software@Risk (developed by Palisade Corp.) is used to analyze the magnitude and confidence limits of risk (Stochastic budgeting) that can be used by decision makers (farmers) to decide which alternatives will be chosen (irrigation method and types of crops) according to their attitude toward risk or their capability to bear risk.

\section{DATA SOURCES}

This study focused on the coastal paddy field in South Sulawesi, where the meteorological data was obtained from climatology stations in Ujung Pandang (Makassar) and Maros. Groundwater data was obtained from Indonesian Directorate of Geology, Hydrogeological map sheets no. 2108, 2109 and 2110. Crop production data collected from The Directorate General of Food crops Department of Agriculture of South Sulawesi and the local commodity prices compiled from the regional Central Bureau of Statistics, regional Department of Agriculture of South Sulawesi and from farmers interview.

\section{SEASONAL MODEL}

This research conducted under seasonal model (Dinar and Letey, 1996). The concept of seasonal model integrates parameters of the crops environment and field data to generate a response function in order to optimize the operational on the field level. The model can be run under variety of conditions to generate data necessary for various response functions. The schematic diagram of the Seasonal Model is shown in Fig. 1.

Seasonal models have been used and tested for various crops since 1984, and results have been published in many journals (Letey et al. 1985; Letey et al. 1984; Letey and Dinar 1986; Letey et al. 1990; Dinar and Letey 1996).

The seasonal model In this study is used to predict crop production for several types of crops that are usually grown by local farmers in South Sulawesi. The model was run for different crops, over relevant ranges of applied irrigation water, salinity levels (of the 
irrigation water), and application method. The study analyses the inter-relationship of variables to optimize the expected returns among the crops. Four factors considered in the model, i.e., the Aquifer system, Irrigation technology, agronomic and weather parameters and the economic aspect (Fig. 2).

Four basic requirements are assumed in the model: 1) the groundwater extraction from aquifer is small enough to prevent saline intrusion from the shore lines, and total groundwater discharge should not exceed the rate of ground water recharge, 2) the system capacity is sufficient to supply the irrigation water requirement, 3) the irrigation technology is affordable for the local farmer, and 4) the return of the project is economically sound.

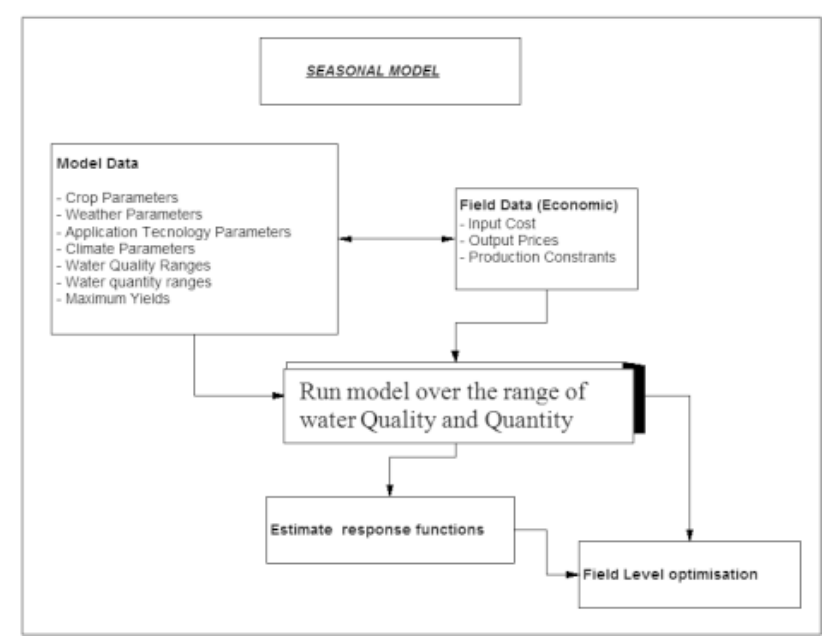

Fig. 1 Scheme of irrigation on seasonal model

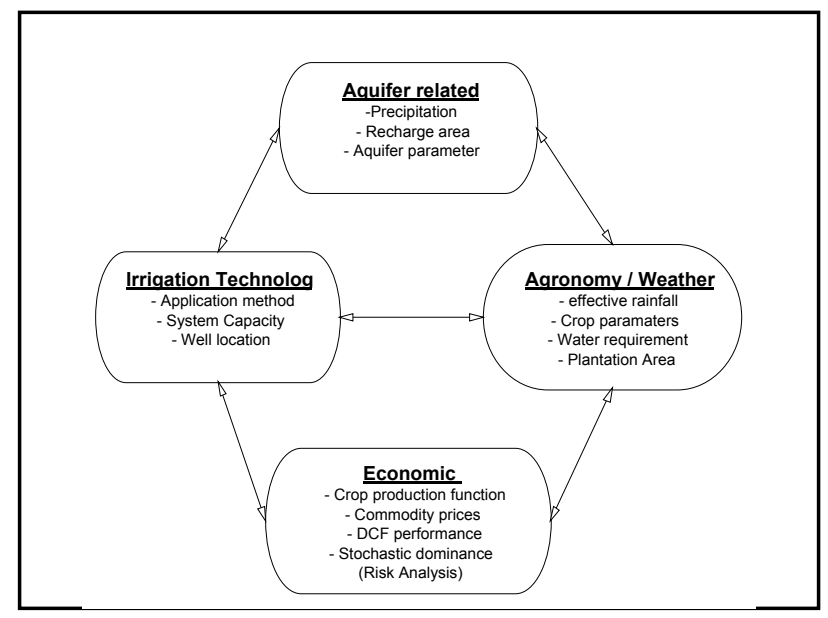

Fig. 2 Schematic diagram of the study

\section{MODEL DEVELOPMENT AND ANALYSIS}

Irrigation System Design
Irrigation design follows the procedure in which the most desirable watering frequency and depth are matched with the capacity and availability of the water supply, involves the field design and field layout.

The model is run under assumption considers a 1-ha of land irrigated from shallow water table by a pump on a rotational schedule from a well located in the center of the field, and the water delivery system using gated pipes perpendicular in four direction of the field. Two irrigation technologies are considered, i.e., furrow irrigation and border irrigation. This system designed suitable for the average land condition of the existing paddy fields in the region. The furrow technique is selected due to its suitability for the row crops, where small applied depth of water is required, while the border system considered due to the labor efficiency. The field is divided into 4 areas $(50 \mathrm{~m} \times 50 \mathrm{~m})$ to improve the water application efficiency, and the water is delivered through the middle of the field by gated pipe.

The well capacity is based on the ground water survey on borehole tests in Makassar, Maros and Pangkajenne region made by The Indonesian Directorate of Natural Geology. Crop water requirements calculated using modified Blaney-Criddle method or FAO-24 (Doorenbos and Pruitt 1977) using the local climatology data from Ujung Pandang (Makassar) and Maros Airport station. Crops are sown in mid-June, and the water requirement for each crop development stages is calculated based on the crop coefficient of each stage and monthly ETo. The maximum water demand of the crops under consideration is used as basic data in determining the pumping capacity (Warring, 1984) to be installed. The irrigation and leaching requirement calculated by Eq. 1 to Eq. 3, and the capacity of the system dictated by the period of maximum crop demand.

$$
V i=\frac{10}{E}\left(\frac{A \cdot I n}{1-L R}\right)
$$

where $\mathrm{Vi}=$ irrigation water requirement $(\mathrm{m} 3 /$ period)

$\mathrm{E}=$ irrigation efficiency (fraction)

$\mathrm{A}=$ crop acreage (ha)

In $=$ net irrigation requirement $(\mathrm{mm} /$ period $)$

$10=$ conversion factor

$\mathrm{LR}=$ leaching requirement (fraction)

The amount of additional water required to leach the potentially built up salt in the root zone (Leaching requirement - LR) is determined based on the applied irrigation water salinity $(\mathrm{ECw})$ and the salinity of soil saturation extract (ECe) and the type of crop to be grown. The leaching requirements are calculated using the following equations: 


$$
\mathrm{LR}=\mathrm{ECw} /(5 \mathrm{ECe}-\mathrm{ECw})
$$

where $\mathrm{LR}=$ leaching requirement (fraction)

$\mathrm{ECe}=$ electrical conductivity of soil extract in the root zone $(\mathrm{ds} / \mathrm{m}$ or $\mathrm{mmhos} / \mathrm{cm})$

$\mathrm{ECw}=$ electrical conductivity of irrigation water $(\mathrm{ds} / \mathrm{m}$ or $\mathrm{mmhos} / \mathrm{cm}$ )

\section{Irrigation Performance}

The optimum irrigation performance of the system is considered in terms of surface irrigation performance criteria, i.e., application efficiency, calculated by Eq. 4 . The infiltration characteristic of the area is represented using the Kostiakov formula in Eq. 5 (Walker and Skogerboe, 1987).

\section{Application efficiency (Ea)}

$$
E a=\frac{\text { Zreq } \mathrm{L}}{\text { Qo } \mathrm{t}_{\mathrm{co}}} \times 100
$$

where Zreq $=$ required depth of application $\left(\mathrm{m}^{3} / \mathrm{m}\right)$ furrow or border

$\mathrm{L}=$ length of run (furrow or border length)

$\mathrm{Qo}=$ flow discharge $(1 / \mathrm{s})$

tco $=$ time of cutoff $(\mathrm{hr})$

$$
\mathrm{Z}=\mathrm{kt}^{\mathrm{a}}+\mathrm{bt}
$$

where $\mathrm{Z}=$ Infiltration depth (mm)

$\mathrm{k}, \mathrm{a}, \mathrm{b}=$ Kostiakov infiltration parameters $(\mathrm{a}=0.547)$

$\mathrm{t}=$ time (min)

The SRFR model ver. 3.0 developed by the US Department of Agriculture (1997) is used to simulate the irrigation performance on the furrow or border length. The irrigation water availability i.e. the maximum discharge of the well will determine the time of cutoff time, optimum size of the border and the discharge into a single furrow or border. The well discharge is based on survey data recorded by the Dir. of Environmental Geology (1998), where the range of well discharges of the region ranges from $5 \mathrm{l} / \mathrm{s}$ to $25 \mathrm{l} / \mathrm{s}$.

Two main criteria are used to determine the optimum performance of the system, i.e., application efficiency (Ea) should be not less than $60 \%$ (adequacy of water supplied in to the root zones) and adequacy of the low quarter average depth of the target infiltration is more than $60 \%$.

The target infiltration is calculated as the irrigation depth required by each type of plant in relation to the soil type.
Crop - water production function

As the model is set up in a spreadsheet, the solver tool is used to calculate the relative yield decrement for certain type of crop under certain quality and quantity of irrigation water applied under certain application uniformity (i.e., $60 \%$ and $80 \%$ ).

The scenario used in this model assumed the amount of water for irrigation is sufficiently provided from the wells. Equation 6 (Dinar and Letey, 1996) then used to calculate crop's potential yield, with various water quality and application efficiency, while the parameters used in model runs shows in Table 1.

Two main equations have been developed to calculate the relationship between potential crop yields and water qualities and quantities with different application uniformity applied in to the field expressed in Eq. 6.

$$
\begin{aligned}
& \frac{100 .\left(Y^{d}\right)^{2}}{B . s \cdot(\beta n \cdot W-W t)}+Y^{d} \cdot S^{\prime}-0.5 E C w . s \cdot \beta n \cdot W-0.1 E C w . s \cdot \beta n \cdot W \cdot \ln \left[\frac{Y^{d}}{\beta n \cdot W \cdot s}+\left(1-\frac{Y^{d}}{\beta n \cdot W \cdot s}\right) \cdot e^{-5}\right]=0 \\
& \left(\mathrm{Wt}<\mathrm{W}<\mathrm{E}_{\max }\right) \\
& S^{\prime}+\frac{100 . Y^{d}}{B \cdot Y^{\max }}-\frac{0.5 E C w}{1-\frac{E_{\max }}{\beta n \cdot W}+\frac{Y^{d}}{\beta n \cdot W \cdot s}}-\frac{0.1 E C w}{1-\frac{E_{\max }}{\beta n \cdot W}+\frac{Y^{d}}{\beta n \cdot W \cdot s}} \cdot \ln \left\{1-\left[\frac{E_{\max }}{\beta n \cdot W}+\frac{Y^{d}}{\beta n \cdot W \cdot s}\right]\left(1-e^{-5}\right)\right\}=0
\end{aligned}
$$

$(\mathrm{W} \geq$ Emax)

where $Y^{\text {max }}=$ Crop maximum yield (\%) - the maximum yield compared to the potential

$Y^{d}=$ yield decrements $(\%)$

$s=$ slope of crop-water production function $(\% / \mathrm{mm})$

$S^{\prime}=$ threshold salinity $(\mathrm{ds} / \mathrm{m})$ - the maximum salt level of irr. water where crop yield start to decrease

$B=$ slope of yield-salinity curve at salinity range $\mathrm{Se}>\mathrm{S}$ ' $(=100 /(\mathrm{ECe}$ at $0 \%$ yield $-\mathrm{ECe}$ at $100 \%$ yield or from table) $(\% \mathrm{ds} / \mathrm{m})$

$E C w=$ irrigation water salinity $(\mathrm{ds} / \mathrm{m})$

$W=$ amount of water applied (\% from optimum required)

$W t=$ amount of water applied when yield $=0(\%$ of optimum required)

$E_{\max }=$ crops' maximum evapotranspiration $(\%$ from potential)

$\beta n=$ distribution uniformity of irrigation water over the field (fraction)

The input variables for potential yield decrement for each crop under consideration are:

(1) Threshold salinity $\left(S^{\prime}-\mathrm{ds} / \mathrm{m}\right)$ obtained from published tables such as Rhoades et al (1992)

(2) Slope of Yield-salinity curve $(B-\% / \mathrm{ds} / \mathrm{m})$ from Tables 13 and 14, Rhoades 1992

(3) Irrigation water salinity $(E C w-\mathrm{ds} / \mathrm{m})$ (i.e., Salinity of shallow groundwater under the paddy fields) using the groundwater survey data (from Dir. of Env. Geology -1998) 
(4) Quantity of applied water ( $W$ - \% from oopt. req.) The model fix inputs are:

(1) Maximum relative evapotranspiration of the crop $\left(E_{\max }-\%\right)$

(2) Maximum relative yield ( $\left.Y^{\max }-\mathrm{t} / \mathrm{ha}\right)$ obtained from crop production statistic of South Sulawesi

(3) Production function slope $(s-\% / \mathrm{mm})-$ calculated or from table
(4) Applied water when crops' yield equals reach the maximum of potential yield $\left(\mathrm{Y}^{\mathrm{max}}\right)$

(5) Lowest quantity of applied water ( $W t-\%$ of pot.) obtained from table

Table 1 Input parameters for crop production functions

\begin{tabular}{|c|c|c|c|c|c|c|c|c|c|c|c|}
\hline \multirow[b]{2}{*}{ Crops } & \multicolumn{5}{|c|}{ Crop Parameters } & \multicolumn{3}{|c|}{ Salinity } & \multirow{2}{*}{$\begin{array}{l}\text { Man } \\
\text { age- } \\
\text { ment } \\
\text { Unif } \\
\text { or- } \\
\text { mity }\end{array}$} & \multicolumn{2}{|c|}{ Absolute Values } \\
\hline & $\begin{array}{l}\text { Max. } \\
\text { Yield }\end{array}$ & $\begin{array}{l}\text { Max } \\
\text { Et }\end{array}$ & $\begin{array}{l}\text { Min } \\
\text { ET }\end{array}$ & $\begin{array}{l}\text { Water } \\
\text { applic } \\
\text { ation }\end{array}$ & $\begin{array}{l}\text { Y-Wt } \\
\text { Slope }\end{array}$ & $\begin{array}{l}\text { Tres- } \\
\text { hold }\end{array}$ & $\begin{array}{l}\text { Y-S } \\
\text { slope }\end{array}$ & $\mathrm{ECw}$ & & $\begin{array}{l}\text { Crop } \\
\text { Yield }\end{array}$ & $\begin{array}{l}\text { ET/ } \\
\text { season }\end{array}$ \\
\hline units & $(\%)$ & $(\%)$ & $(\%)$ & $(\%)$ & $(\% / \mathrm{mm})$ & $(\mathrm{ds} / \mathrm{m})$ & $(\% / \mathrm{ds} / \mathrm{m})$ & $(\mathrm{ds} / \mathrm{m})$ & $\%$ & (ton/ha) & $(\mathrm{mm} / \mathrm{ssn})$ \\
\hline symbols & $\mathrm{Y}^{\max }$ & $\mathrm{E}_{\max }$. & $\mathrm{Wt}$ & $\mathrm{W}$ & $\mathrm{s}$ & $\mathrm{S}^{\prime}$ & B & $\mathrm{C}$ & $\beta n$ & - & - \\
\hline Corn & 100 & 100 & 2.781 & $\mathrm{tba}^{+}$ & 1.03 & 1.7 & 12.04 & tba & tba & 8 & 374 \\
\hline Soybean & 100 & 100 & 2.66 & tba & 1.03 & 5 & 20 & tba & tba & 3.5 & 356 \\
\hline Groundnut & 100 & 100 & 12.54 & tba & 1.14 & 3.2 & 29.4 & tba & tba & 4 & 142 \\
\hline C.Pepper & 100 & 100 & 2.473 & tba & 1.03 & 1.7 & 12 & tba & tba & 8.7 & 368 \\
\hline Tomato & 100 & 100 & 13.65 & tba & 1.16 & 2.5 & 9 & tba & tba & 45 & 375 \\
\hline Mungbean & 100 & 100 & 6.806 & tba & 1.07 & 1 & 19 & tba & tba & 1.5 & 191 \\
\hline
\end{tabular}

${ }^{+}$tba means to be assigned on the model run

Well system

A one-dimensional system approach to an aquifer with recharge area assuming the aquifer lies between two parallel ditches has been explained by Huisman (1972), were the water table position at a certain point can be calculated under a certain rate of recharge from precipitation or irrigation and under certain value of hydraulic conductivity. Groundwater abstraction from the aquifer through pumping wells will result in lowering the water table. Before pumping starts, the water table is considered horizontal if there has been no recharge by rainfall nor loss through evapotranspiration (Huissman, 1972). The schematic diagram of watertable in a pumping well illustrated in Fig 3.

The flow of groundwater into the well calculated using steady state condition. The Dupuit equation (Todd, 1980) is used to calculate the drawdown in a steady state condition, where the radius of influence is constant at a certain rate of pumping expressed as:

$$
s=\frac{Q o}{2 \pi k H} \ln \frac{R}{r}
$$

where $\mathrm{s}=$ well drawdown

$Q_{\mathrm{o}}=$ well discharge
$H=$ aquifer thickness

$R=$ radius of influence

$r=$ well radius

$k=$ hydraulic conductivity

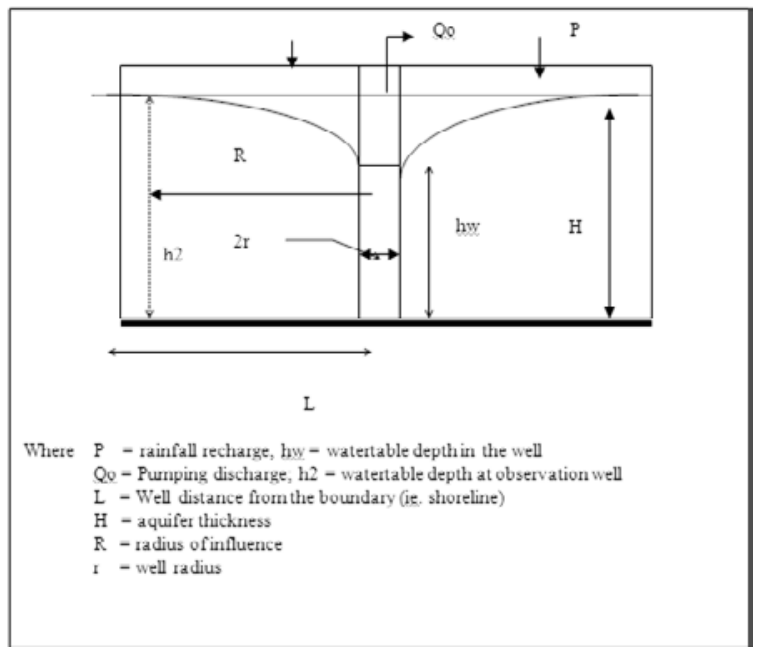

Fig. 3 Schematic diagram of water table in a pumping well

Economic Analysis 
Economic analysis based on the profit the farm income where the total revenue is calculated by multiplying price times output. The farm profit calculated by Eq. 8 using the potential crop yield elicited from crop-water production model. In this case, the most likely value of irrigation water is used, and the commodity prices using the average commodity price from Agricultural Statistics of South Sulawesi, 200-2011. Pump, pipes and accessories prices obtained from the local market in Makassar regions.

General overheads considered are general farm maintenance, insurance, and family expenditure (assumed the family expenses are partly covered by other sources).

The Discounted Cash flow method (Helmberger and Chavas 1996) (Eq. 9 to Eq. 12) is used to measure the economic performances of the project to determine the reliability of the investment.

$$
\Pi=\mathrm{TR}-\mathrm{TVC}-\mathrm{TFC}
$$

where $\Pi=$ profit

$\mathrm{TR}=$ total revenue

$\mathrm{TVC}=$ total variable cost

$\mathrm{TFC}=$ total fix cost

$$
N P V=\sum_{t=0}^{n} \frac{P V}{(1+r)^{t}}
$$

where NPV $=$ net present value

$r=$ interest rate

$t=$ the amount of years considered

$$
E A W=N P V \frac{(1+r)^{t} r}{(1+r)^{t}-1}
$$

where $E A W=$ Equivalent Annual Worth

$$
B C R=\frac{\sum_{t=0}^{n} \frac{F B t}{(1+r)^{t}}}{\sum_{t=0}^{n} \frac{F C t}{(1+r)^{t}}}
$$

where $B C R=$ Benefit Cost Ratio

$F B t=$ profit before tax

$F C t=$ total cost (capital and operating cost)

$$
\mathrm{IRR}=\mathrm{r} \text { where } \mathrm{NPV}_{\mathrm{r}}=0
$$

where $I R R=$ Internal Rate of Return

\section{RISK ANALYSIS}

There are many terms used in defining 'risk'. It is commonly suggested that the term 'risk' can be defined as imperfect knowledge, where the probabilities of the possible outcomes are known, while the term 'uncertainty' describes when these probabilities are not known (Hardaker et al, 1997). Accounting for risk is important in agriculture which may be exposed to many risks of various magnitudes, such as extreme weather conditions, diseases, pests and animal destruction.

Dry land farming is prone to risks of environmental crises and catastrophes, challenges and changes. Unpredictability and severity of climatic events is rivaled by the dispersion of relevant probability distributions and human difficulty of comprehending and managing probabilities of relatively rare events (Anderson and Dillon 1992). The source of risks in agriculture can be in the forms of production risks, market risks, financial risks, human or personal risks and, institutional risks (Hardaker et al 1997).

\section{RESULT AND DISCUSSION}

The systems' cash flow over ten consecutive years life span is expressed in terms of present value at a $10 \%$ discount rate. Some assumptions are applied in calculating the system' returns i.e., the project only utilizes the paddy field for secondary crop plantation once in a year during the dry period which is normally from June to October. The project is assumed to be implemented on a one-hectare rented land and the pump purchase is the part of the project's capital cost.

The cash flow performance of the project considers both Furrow and Border methods as application uniformity, and the difference in cost is mainly due to labor and annual energy costs. System's performance is given based on the different irrigation water salinity where the cash flow performance is affected by the yield reduction due to the saline irrigation water effects on the crop yield. The irrigation water salinity used are $3 \mathrm{ds} / \mathrm{m}$ and $7 \mathrm{ds} / \mathrm{m}$ (based on the survey data) and crop yield is obtained from the crop production function sub-model. The result shows that three crops are dominant in the gross margin on both $3 \mathrm{ds} / \mathrm{m}$ and $7 \mathrm{ds} / \mathrm{m}$ of water salinity under $80 \%$ irrigation application uniformity i.e tomato $>$ Chili pepper and Groundnut (Useng et al. 2012). These three type of crops shows the dominance over the other three crops i.e., corn, soybean and mungbean. The revenue of the three dominant crops under two different irrigation application uniformity (Ea $80 \%$ and $60 \%$ ) shown in Fig. 4, and the surface response function of 
these three dominant crops showing the potential yields under different irrigation water salinity and water application (ratio of actual evapotranspiration over the maximum - $\left.E / E_{\max }\right)$ shown in Fig. 5.

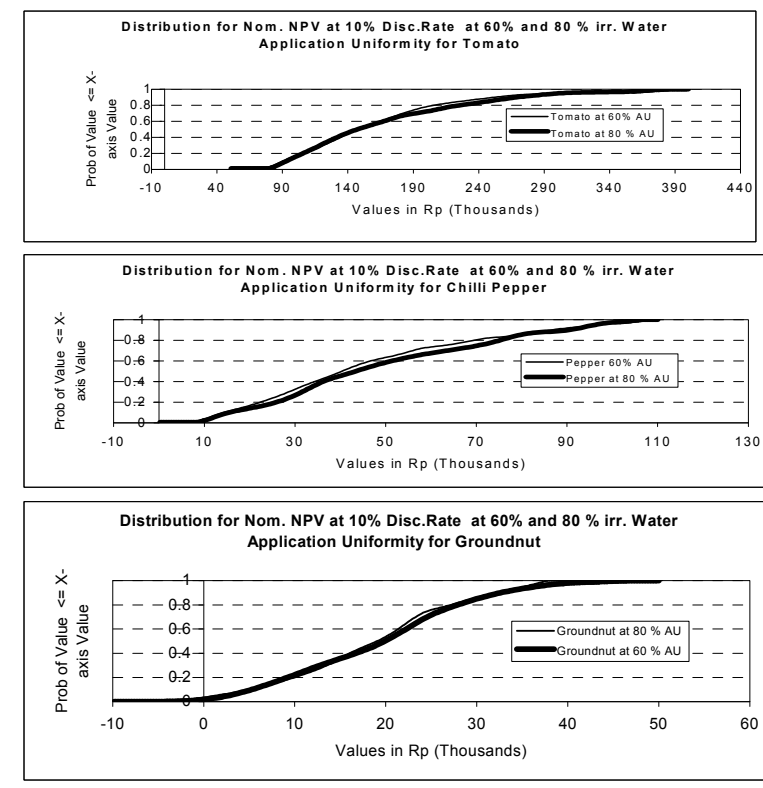

Fig. 4 Cumulative Distribution Function (CDF) for different water application uniformity ( $80 \%$ and $60 \%)$ of tomato, groundnut and chili pepper

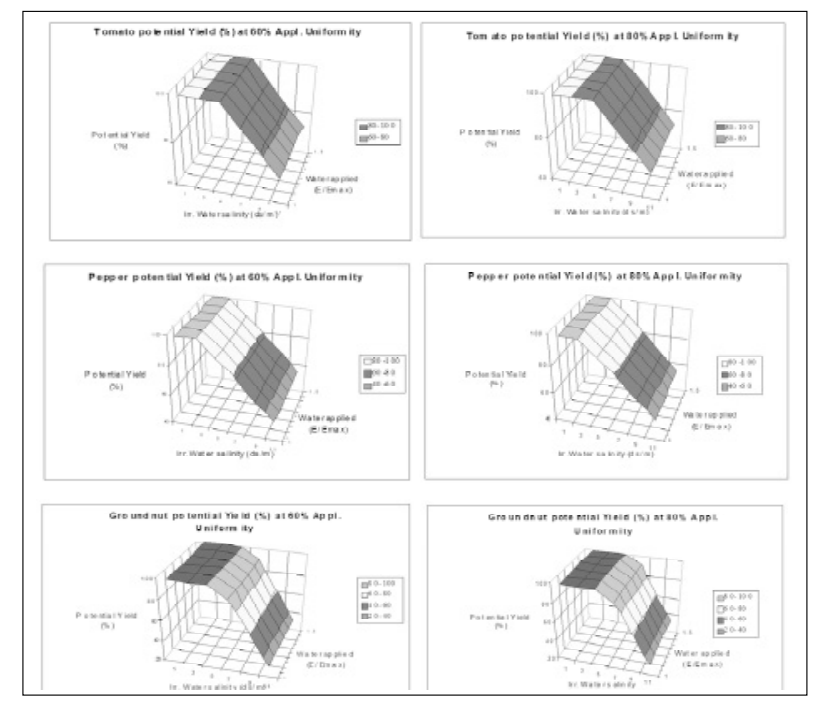

Fig. 5 The Surface response curve (Crop production function) for tomato, chili pepper and Groundnut under $60 \%$ and $80 \%$ application Uniformity

\section{Risk Simulation Output}

The risk efficiency of each crop under crop is shown by overlaying the cumulative distribution function (CDF) of each crop. Here we used the CDF of the nominal net present values (NPVs) at 10\% discount rate to show the stochastic dominance for all type of crop considered. For detail see Useng et al. (2012). The risk efficiency of each crop, where tomato is the most riskefficient crop to be grown, followed by chili pepper and groundnut, while mungbean and soybean have a high probability of loss. The risk performance shows that only slight differences occur between furrow $(80 \%$ application uniformity -AU) and border irrigation system (60\% AU). Even though, the furrow system ( $80 \% \mathrm{AU})$ is still dominant than the border system $(60 \% \mathrm{AU})$.

The risk analysis (tomato case) shows the most risky period is in the first planting season where the range of uncertainty spread from Rp. $38 \times 10^{6}$ (maximum) to Rp. $6.14 \times 10^{6}$ (minimum) with the mean of Rp. $19.06 \times 10^{6}$, and reduced as the project years progresses, at the end of the project (the $10^{\text {th }}$ planting season), the range of uncertainty reduced to Rp. $26.8 \times 10^{6}$ (max.), Rp. $6.83 \times$ $10^{6}$ (min.) and $12.3 \times 10^{6}$ (mean). The risk performance of the project under inflation shows an inverse trend, where the widest span of uncertainty occurs at the end of the project as influenced by uncertainty about the inflation rate. For more detail see Useng et al. (2012). The risk distribution at year 1 and year 10 is shown in Fig. 6.

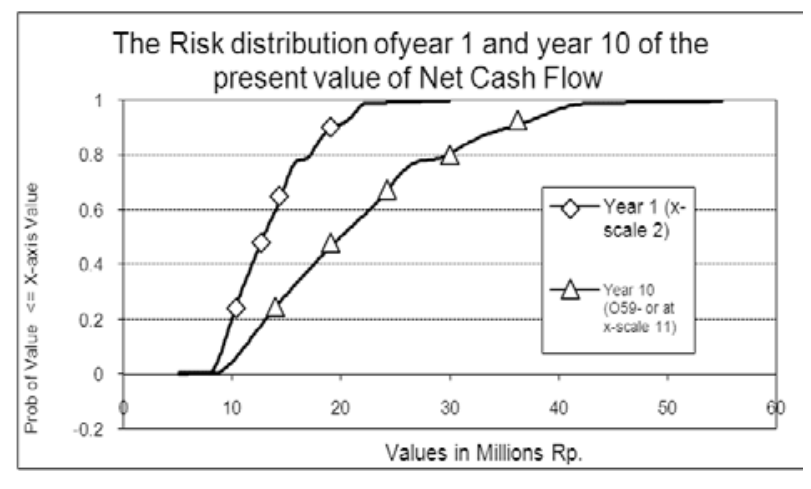

Fig. 6 Cumulative distribution function (CDF) of uncertainty for net cash flow at year 1 and year 10 (tomato case)

Sensitivity analysis

Sensitivity analyses are performed to rank the input variables' influence on the model output. Input distributions which are significant factors determining the output variable value calculated by rank correlation, where the correlation coefficients calculated between the output values and each set of sampled input values. The magnitude of each input impact to the output is shown on the size of that particular input on the graph, where a positive correlation means that when the input value samples 'high', the output values are also high. A negative correlation means the output is low when the input is high. 
The typical input sensitivity to the output shows in Fig. 7. The input sensitivity shows that commodity price is the most sensitive input for the project NPVs, the irrigation water salinity and operational cost are the second and the third rank respectively, while for the nominal net cash flow, inflation rate is the second determinant factor.

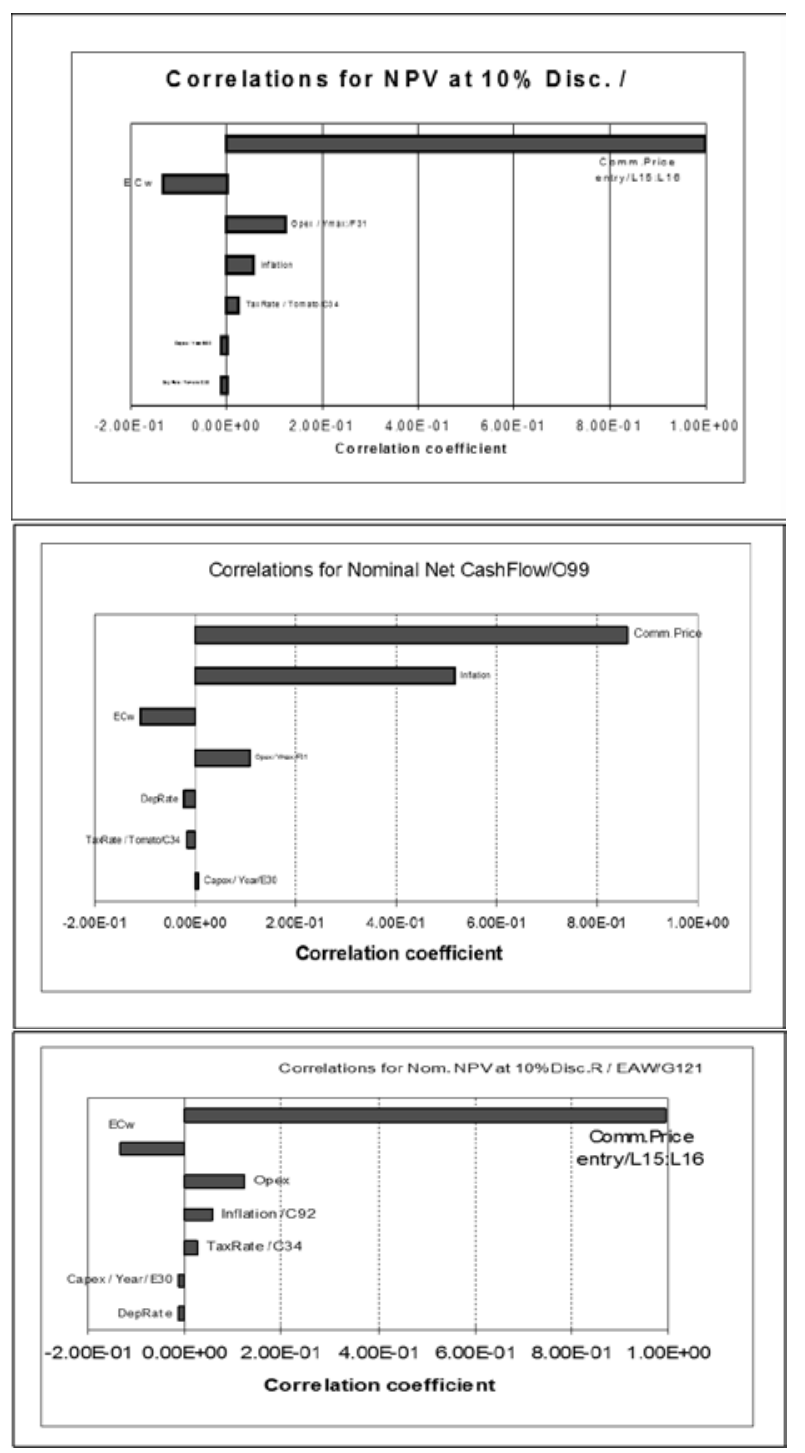

Fig. 7 The rank of the input sensitivities to the model outputs shows the commodity price is the most sensitive to the model output (positive corr.) while the water salinity $(\mathrm{ECw})$ has negative correlation

\section{CONCLUSIONS}

Three main conclusions derived from this study are: 1) The irrigation technology of both furrow and border irrigation for secondary crops plantation on the paddy fields have similar returns, therefore the irrigation technology is not a major issue in irrigation technology selection. The soybean, corn and mungbean are risky to be gown under the scenario, and the most promising crops (less risky) to be are tomato, chili pepper and groundnut. 2) The financial performance of the project has a negative correlation with the irrigation water salinity and depends heavily on the crop's salt tolerance. 3) Market risk (commodity prices) are the most important determinant influencing the project return followed, by irrigation water salinity and operational costs respectively in the project NPVs, while the inflation rate is the second rank in determining the risk for nominal net cash flow.

\section{ACKNOWLEDGEMENT}

The author expresses many thanks to the Dir. Gen. of Higher Degree (Dirjen DIKTI) of the Indonesian Education Ministry for the support of this research and the Dept. of Agric. of Hasanuddin University for facilitating the research. The author attributed great appreciation and thanks to three anonymous reviewers who provided most valuable suggestions for the completion of this paper.

\section{REFERENCES}

Anderson, J.R. and Dillon, J.L. (1992). Risk Analysis in Dryland Farming System. FAO. Rome.

Biro PusatStatistik Indonesia (Indonesian Central Bureau of Statistics) (2010).

Biro PusatStatistik Indonesia (Indonesian Central Bureau of Statistics) Sulawesi Selatan (2011).

DepartemenPertanian Indonesia (Indonesian Dept. of Agriculture) (1998). Area Harvested of foodcrops in Indonesia 1992-1997. [Online] Available WWW: http://www.deptan.go.id/ tabel.

Dinar, A. and Letey, J. (1996). Modelling Economic Management and Policy Issues of Water in Irrigated Agriculture.Praeger Pub. Westport.

Directorate of Environmental Geology - Departemen Pertambangandan Energi (1998). Status of Hydrogeological Mapping of Indonesia scale 1:250.000. [Online] Available WWW: http:/www.dgtl.dpe.go.id/hydro/mapin.html.

Doorenbos, J. and Pruitt, W.O. (1977). Crop Water Requirements. FAO Irrigation and Drainage Paper No. 24 (FAO-24). Rome.

Hardaker, J.B, Huirne, R.B.M. and Anderson, J.R. (1997). Coping With Risk in Agriculture. Cab International. Wallingford. 
Helmberger, P.G. and Chavas, J.P. (1996). The Economics of Agricultural Prices.Prentica Hall. NJ.

Letey, J., Vaux H.J., and Feinerman, E. (1984). Optimum Crop Water Application as Affected by Uniformity of Water Infiltration. Agronomy Journal. 76: 435-441.

Letey J., Dinar, A. and Knapp, K.C. (1985). Crop-water Production Function Model for Saline Irrigation Waters.Jour. of Soil Science. 49: 1005-1009.

Letey, J. and Dinar, A. (1986). Simulated Crop-Water Production Functions for Several Crops. Hilgardia. 54(1).

Letey, J., Dinar, A., Woodring, C. and Oster, J.D. (1990). An Economic Analysis of Irrigation System. Irrigation Science 11: 37-43
Rhoades, J.D., Kandiah, A. and Masali, A.M. (1992). The Use of Saline Waters for Crop Production.FAO Irrig. And Drainage paper No. 48. Rome.

Todd, D.K., (1980). Ground water Hydrology. John Wiley \& Sons. NY.

Useng D., Achmad, M., Suhardi, Munir, A. and Darmawan (2012). Potential Risk and Returns of Using Shallow Ground water for Secondary Crops on Lowland Paddy Fields: Case study in South Sulawesi. Proc. of the 8th Int. Symposium on Lowland Technology (ISLT). Bali, Indonesia, Sept 11-13: 381-388

Warring, R.H. (1984). Pumping Manual. 7th ed. Gulf Pub. Co. 